\title{
Facebook Analytic to Increase Online Sales (case study: Jual Beli Tegal Group Page)
}

\author{
Slamet Wiyono ${ }^{1}$, Arif Wirawan Muhammad ${ }^{2}$, Dairoh $^{3}$, Muhammad Fikri Hidayattullah ${ }^{4}$, \\ Muhammad Khambali ${ }^{5}$ \\ \{slamet2wiyono@gmail.com ${ }^{1}$, arifw.muhammad@gmail.com² ${ }^{2}$ dairoh@poltektegal.ac.id ${ }^{3}$ \} \\ Politeknik Harapan Bersama, Jl. Mataram No. 9, Pesurungan Lor, Kota Tegal, Indonesia ${ }^{1234}$ \\ Politeknik Negeri Semarang, Jl. Prof. H. Soedarto, S.H., Tembalang, Semarang, Indonesia ${ }^{5}$
}

\begin{abstract}
Jual Beli Tegal is one of the popular Facebook group pages in Tegal city. Various ways are done to market the goods to be sold in the group. However, not know which way is the most effective to put an ad in the Jual Beli Tegal group. R-tools is used for data crawling and data analytics. After analyzing, the information obtained as follows: the number of likes and comments follows the trends in the number of ads. If ad trends increase then the likes and comments trends are also increasing and if the advertising trend decreases then the like and comment trends are also decreasing, the best way to advertise on the group page Jual Beli Tegal is by using photos with adding a message, and the best time to advertise on the group page Jual Beli Tegal is in June and July on all dates.
\end{abstract}

Keywords: facebook analytics, r-tools, data analyze.

\section{Introduction}

Nowadays, social media is growing rapidly. For example, in 2017 there are 2.789 Billion active social media account, an increase of $20 \%$ from 2016 . From active social media account, Facebook is the most popular social media in the world with a total of 1,871 billion users by 2017 [1]. Facebook is also a popular social media in Indonesia. Facebook active users in Indonesia are ranked 4th in the world [2]. Indonesian people use Facebook for various activities. One of the activities they often do on Facebook is buying and selling.

Jual Beli Tegal is one of the popular Facebook group pages for buying and selling in Tegal city. The group was created in 2010. Jual Beli Tegal has 102,129 members [3], while the population of Tegal city is 275,982 inhabitants [4]. Thus almost half of Tegal city residents are members of Jual Beli Tegal.

Tegal city people often use Jual Beli Tegal to advertise. Various ways are done to market the goods to be sold in the group. Various ways are done to attract group members' attention to the advertisements offered. Some using text descriptions, some using photos and text, some using videos, and various other ways. However, from the various ways that have been done not know which way is the most effective to put an ad in the Jual Beli Tegal group. Thus, an analysis of the group is required to find out how best to advertise in the group.

Data analytics is the science of raw data analysis with the aim of obtaining the conclusion of an information. Data analytics is mostly done by many companies for better business decision making [5]. For example, research on the prediction of Nike shoe sales. The research uses Facebook data to determine the social media users' responses to their products and to understand

ICCSET 2018, October 25-26, Kudus, Indonesia

Copyright (C) 2018 EAI

DOI 10.4108/eai.24-10-2018.2280545 
the exact way and time for product promotion [6]. Data analytics is also often used for political purposes. For example, research for predicting the 2015 Finnish parliamentary elections. The research uses Facebook likes and public opinion to make election predict [7]. Besides being used for companies and political purposes, data analytics is also used to determine public satisfaction with government services. For example, research to create a social media text analytics framework for citizen-centric public services. The research uses Facebook citizens' posts and comments on a local government's department Facebook page [8]. In addition, data analytics are also used in intelligent transport, such as research conducted by Li Zhu, Big Data Analytics in Intelligent Transportation Systems: A Survey [9]

The growth of internet usage is growing rapidly. By 2017 there are 3,773 billion active Internet users, up 21\% from 2016 [1]. The rapid growth is also increasing the performance of the system for data processing analysis [10]. These conditions make the growing interest of researchers about big data, which is about big data analytics and a system to analyze big data [11]. Big Data is a process to deliver decision-making insights. The process uses people and technology to quickly analyze large amounts of data of different types (structured data and unstructured data, such as video, pictures, social media interactions, transaction data, and email) from a variety of sources to produce a stream of actionable knowledge [12].

To produce optimal analytics, synergy is required between big data, internet and dynamic systems. It requires the right tool to perform big data analytics [13]. There are many for analyzing data, $\mathrm{R}$ is one of them. $\mathrm{R}$ is a tool for statistics and data modeling [5]. $\mathrm{R}$ is a versatile language, elegant and expressively syntactic and also has good graphical capabilities [14].

In this research, we analyze big data Facebook using R-tools. The analysis is done to get the best way to advertise at Jual Beli Tegal group page. R-tools is used for data crawling and data analytics. The research questions discussed in this paper are (1) how to obtain data Facebook page and analyze the data using R-tools? (2) how the best way to advertise on the group page Jual Beli Tegal? (3) when the best time to advertise on the group page Jual Beli Tegal?.

\section{Methods}

\subsection{The Material}

a. Data

In this research, we use according to post data and comment posted in Jual Beli Tegal's Facebook group since 2011 to 2017. Data used i.e: type post, mont post, date post, likes count, and comments count.

b. Software Application

In this research, we use some application software i.e: web application (Facebook), operating system (Windows 7), Microsoft Office (Excel), and tools R Studio.

\subsection{Method}

Proposed study of Facebook analytic data exploration to increase online selling growth rate involves four steps as seen on Figure 1. [15] 


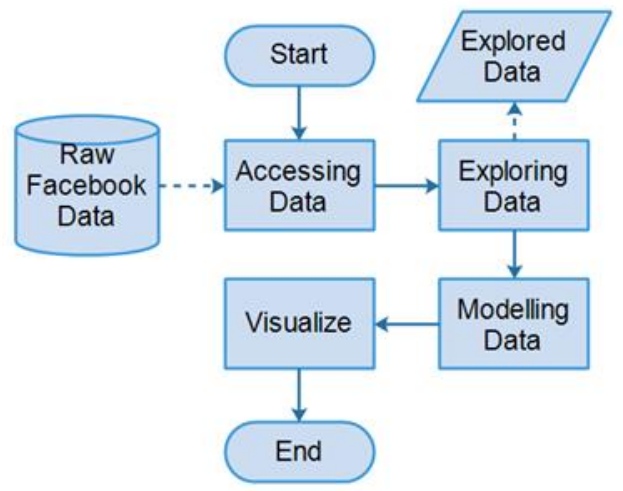

Fig .1. Proposed method to analyzing facebook data.

First, accesing Facebook data. In this study, the first important steps is accessing Facebook data from "Grup Jual Beli Tegal" using R-Studio software crawler. In this steps includes also extraction proccesses in terms transforming raw complex data into unary simpler form. The output of this step is used as input of data exploration process. Second, exploring data. Data exploration is a useful step in determining the technique of presenting data accurately, so that data can be processed into useful information. In this study, data exploration was conducted using software R-Studio. Third, modelling data. Data modeling is the step of data transformation from logical form to visual form. Data modeling makes it easy for users to read and determine data visualization techniques. Fourth, visualizing result. Data visualization is the last step that is very important to facilitate the user in reading the results of analysis that has been implemented previously. Data visualization helps the user to determine the right strategy in carrying out the next business process.

\section{Results And Discussion}

\subsection{Jual beli tegal group pages data}

R-tools is used as data crawler application. Jual Beli Tegal group pages data obtained from 2011 to 2017 are shown in Table 1. Before analyzing the data, the data is edited first by removing duplicate data. Table I shows the data before editing (163030 data) and after editing (162920 data), there are 110 duplicate data. 
Table 1. Jual beli tegal group pages data.

\begin{tabular}{llll}
\hline \multirow{2}{*}{ Ad Post Time (year) } & \multicolumn{2}{c}{ Ads Count } & \multirow{2}{*}{ Duplicate Data } \\
\hline 2011 & Before Edit & After Edit & \\
2012 & 91 & 91 & 0 \\
2013 & 1568 & 1568 & 0 \\
2014 & 53359 & 53350 & 9 \\
2015 & 41882 & 41873 & 9 \\
2016 & 22765 & 22756 & 9 \\
2017 & 24942 & 24861 & 81 \\
Total & 18423 & 18421 & 2 \\
\hline
\end{tabular}

Clean data (no duplicate data) is shown in Table II. The table is data each year that shows the number of ads, number of likes, and number of comments.

Table 2. Data after delete duplicate value.

\begin{tabular}{cccc}
\hline $\begin{array}{c}\text { Ad Post Time } \\
\text { (year) }\end{array}$ & $\begin{array}{c}\text { Ads } \\
\text { Count }\end{array}$ & $\begin{array}{c}\text { Comments } \\
\text { Count }\end{array}$ & $\begin{array}{c}\text { Likes } \\
\text { Count }\end{array}$ \\
\hline 2011 & 91 & 97 & 55 \\
2012 & 1568 & 7975 & 3272 \\
2013 & 53350 & 544514 & 69938 \\
2014 & 41873 & 346600 & 46294 \\
2015 & 22756 & 144603 & 28714 \\
2016 & 24861 & 108373 & 36696 \\
2017 & 18421 & 62689 & 44611 \\
Total & 162920 & 1214851 & 229580 \\
\hline
\end{tabular}

The number of Jual Beli Tegal Ads increased from 2011 to 2013, then decreased until 2015, then slightly increased until 2016, then decreased again until 2017 as shown in Figure 2. The year 2011 is the year with the least number of ads, this is possible because the group Jual Beli Tegal is new and the number of members is still small. In 2013 the number of ads began to decrease and continue to decrease until 2017, this could be due to emergence the new groups' pages to do sell and buy in the area of Tegal City and surrounding areas. The emergence of new buying and selling groups make the people of Tegal City and its surroundings not always used Jual Beli Tegal group for put an ad, so the number of ads decreases. Figure 3 shows the growth of group pages Facebook of buying and selling in Tegal City and surrounding areas. In 2011 there is only one group, in 2012 there are 2 groups, in 2013 there are 7 groups, and continue to grow to 25 groups in 2017. 


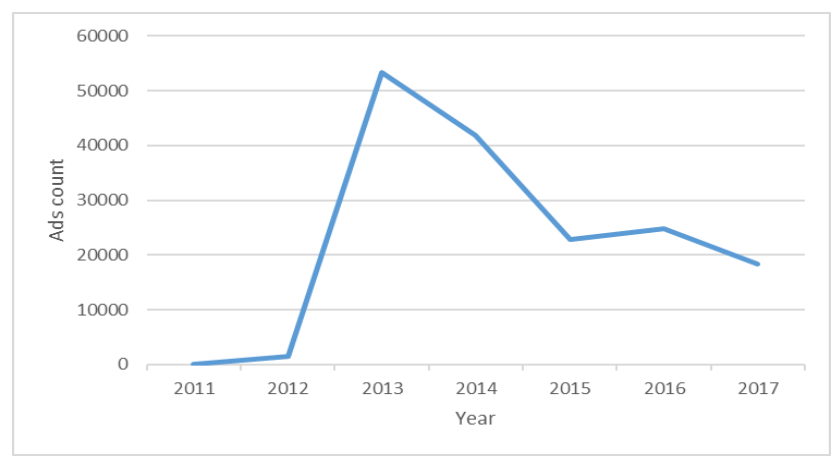

Fig. 2. Number of ad post each year.

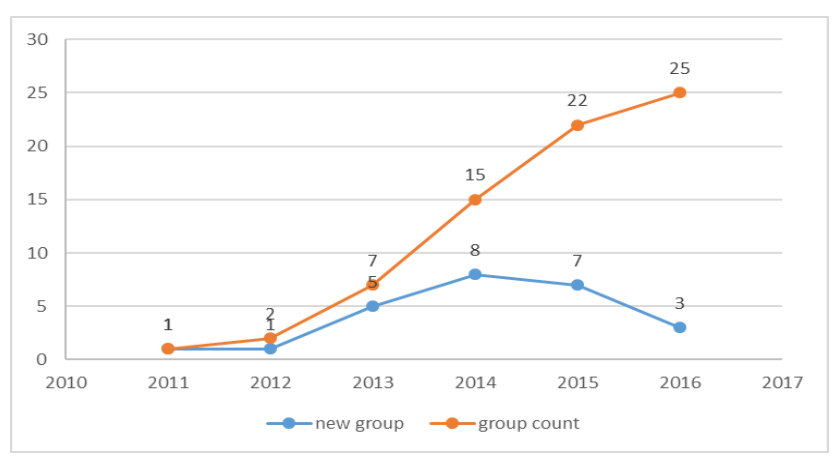

Fig. 3. Growth of buy and sell group page Facebook in Tegal city.

Comments and likes are responses from advertisements that are posted. The number of comments increases from 2011 to 2013 and then declines until 2017. The increase and decrease in the number of comments is in line with the increasing and decreasing number of ads. When viewed from the trend, the number of ads and the number of comments have the same tendency, as shown in Figure 4. Likewise with the likes count, has the same tendency as the number of ads, as shown in Figure 5.

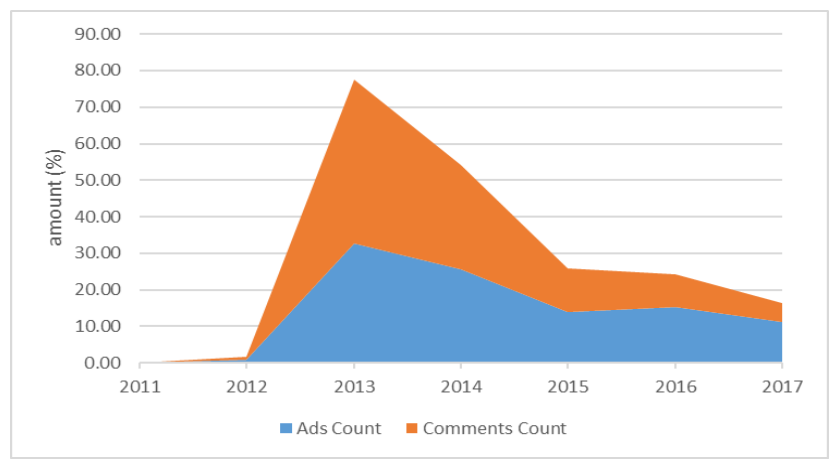

Fig. 4. Relation trend between ads and comments. 


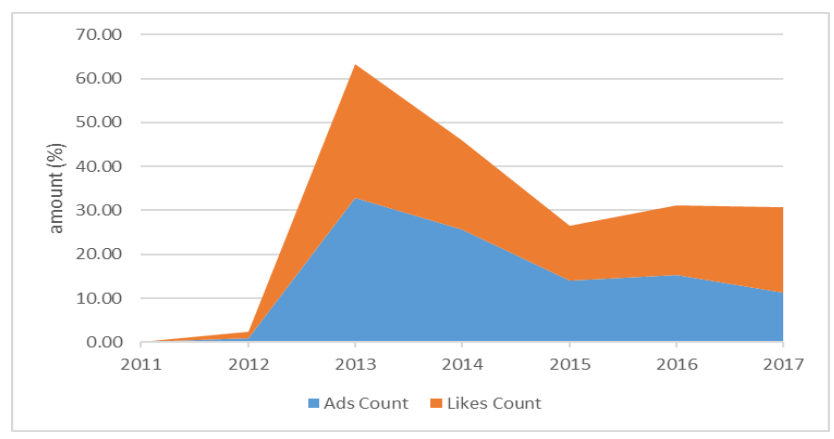

Fig. 5. Relation trend between ads and likes

\subsection{Analysis of ways to post ad}

Various ways of advertising have been done to attract the attention of group members. Table III shows several ways of advertising, number of likes, and the number of comments that appear from the ads being installed. Various ways of advertising is done with some type of post; event without messages, links using messages and without messages, notes using messages, photos using messages and without messages, status using messages and without messages, videos using status and without status.

Table 3. Ways of advertise and sum of likes and comments

\begin{tabular}{lrr}
\hline Type of post & Sum of likes count & Sum of comments count \\
\hline event & 0 & 0 \\
without message & 0 & 0 \\
link & 605 & 2087 \\
without message & 57 & 64 \\
using message & 548 & 2023 \\
note & 2 & 0 \\
using message & 2 & 0 \\
photo & 175549 & 982202 \\
without message & 31311 & 245924 \\
using message & 144238 & 736278 \\
status & 53302 & 230266 \\
without message & 3771 & 6660 \\
using message & 49531 & 223606 \\
video & 122 & 296 \\
without message & 13 & 6 \\
using message & 109 & 290 \\
Grand Total & 229580 & 1214851 \\
\hline
\end{tabular}

Figure 6 shows that advertising using photo is the best way to get likes and comments. The second way is to use status, the third way to use links, the fourth way to use video, while advertising using notes and events is not recommended. The addition of a message at the time of post also affects the number of likes and comments as shown in Figure 7. The figure shows advertisements using photo by adding message gets more like and comment counts than without message. Besides using photos, advertising using status is the same. Advertising using status 
gets more likes and comments than without messages. This shows that the best advertisement is using photo. Additionally, advertising by adding a message will get more likes and comments than without messages.

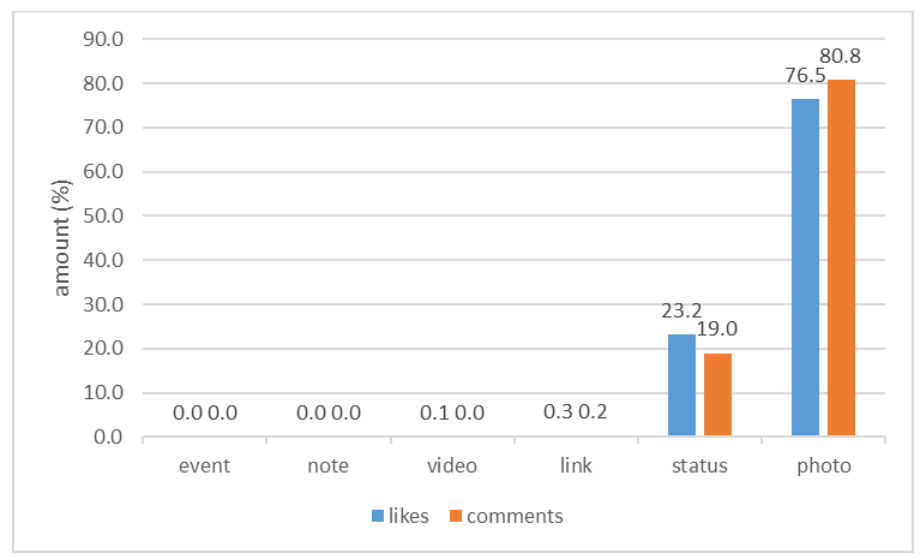

Fig. 6. Number of likes and comments based on ways of advertise.

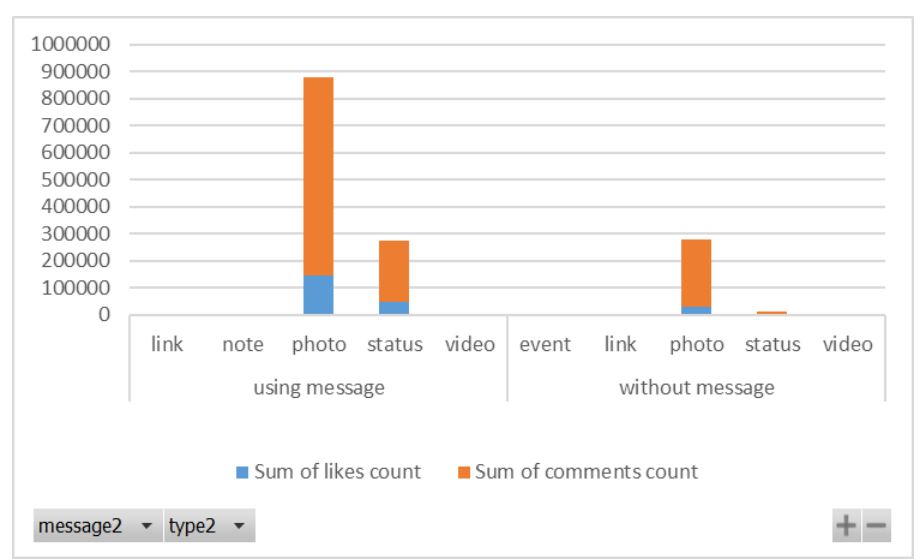

Fig. 7. Number of likes and comments based message.

\subsection{Analysis of times to post ad}

The posting time (month and date) affects the number of likes and comments. Figure 8 shows the number of likes and comments on ads posted on the 1st month through 12 th. The figure shows the number of likes and comments that differ from month to month. The 6th month (June) and the 7th month (July) is the month with the highest number of likes and comments. 


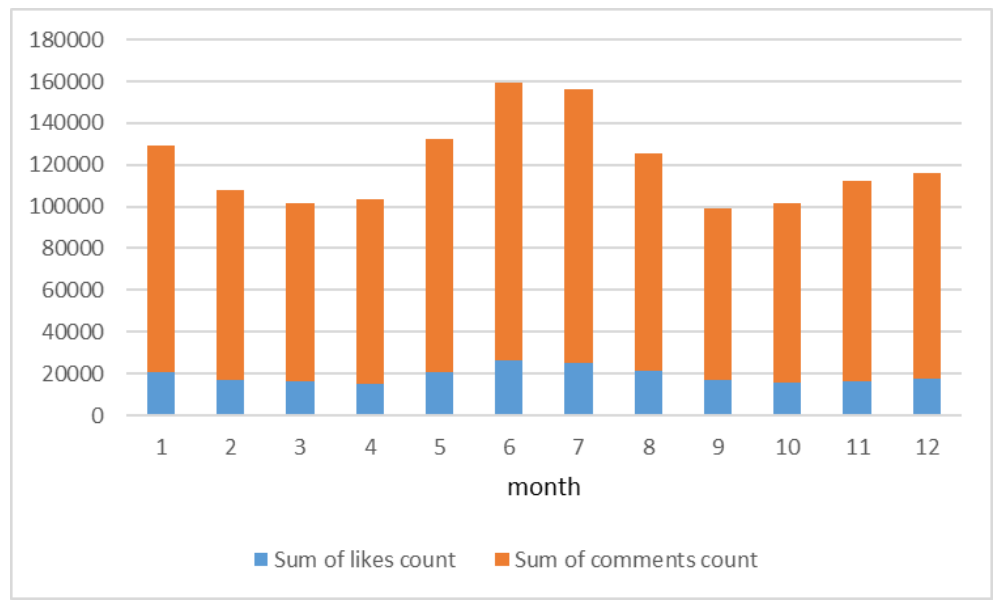

Fig. 8. Number of likes and comments based month of post

Figure 9 shows the number of likes and comments on ads posted on the 1 st through the 31 st. The figure shows almost the same number of likes and comments, except the 31 st. The ads posted on the 31 st get like and comment at least, ie almost half of the other dates. This may be because the 31st is repeated about 7 times while the other dates repeat almost 12 times a year, so the number of likes and comments is almost half of the other dates. Thus it can be said that there is no influence of the post date on the number of likes and comments. Based on the description, it can be concluded that the best time to advertise is June and July month on all dates.

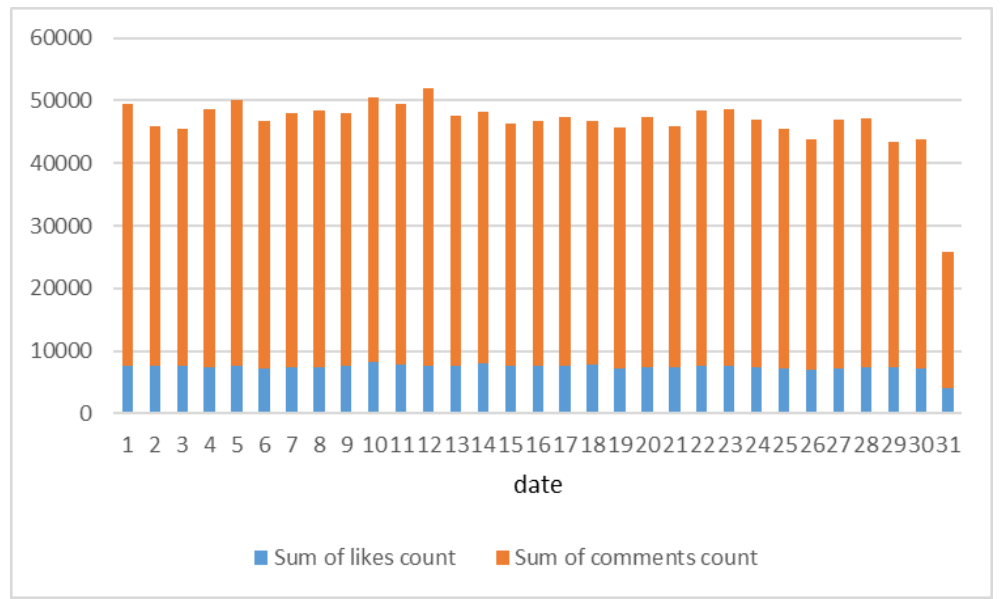

Fig. 9. Number of likes and comments based date of post 


\section{Conclusions}

Data "Jual Beli Tegal" is obtained using R-tools, which is 163030 rows. The data is then cleared by eliminating duplicate data so that it becomes 162920 rows. The clean data is then analyzed to get information. After analyzing, the information obtained as follows: the number of likes and comments follows the trends in the number of ads. If ad trends increase then the likes and comments trends are also increasing and if the advertising trend decreases then the like and comment trends are also decreasing, the best way to advertise on the group page Jual Beli Tegal is by using photos with adding a message, and the best time to advertise on the group page "Jua; Beli Tegal" is in June and July on all dates.

\section{References}

[1] D. Chaffery, "Global social media research summary 2018 | Smart Insights," Smart Insights, 2018. [Online]. Available: https://www.smartinsights.com/social-media-marketing/social-mediastrategy/new-global-social-media-research/. [Accessed: 29-Mar-2018].

[2] " Countries with most Facebook users 2018 Statistic." [Online]. Available: https://www.statista.com/statistics/268136/top-15-countries-based-on-number-of-facebook-users/. [Accessed: 20-Jan-2018].
[3] "(17)
JUAL
BELI TEGAL."
[Online].
Available:
https://www.facebook.com/groups/JUALBELI.TEGAL/about/. [Accessed: 23-Oct-2017].

[4] "Penduduk Kota [Online]. Tegal." Available:

https://tegalkota.bps.go.id/webbeta/frontend/linkTabelStatis/view/id/199. [Accessed: 16-Dec-2017].

[5] A. Malviya, A. Udhani, and S. Soni, "R-tool: Data analytic framework for big data," in 2016 Symposium on Colossal Data Analysis and Networking (CDAN), 2016, pp. 1-5.

[6] L. C. Boldt et al., "Forecasting Nike' s Sales using Facebook Data," in 2016 IEEE International Conference on, 2016, pp. 2447-2456.

[7] T. Vepsäläinen, H. Li, and R. Suomi, "Facebook likes and public opinion: Predicting the 2015 Finnish parliamentary elections," Gov. Inf. Q., vol. 34, no. 3, pp. 524-532, 2017.

[8] C. G. Reddick, A. T. Chatfield, and A. Ojo, "A social media text analytics framework for doubleloop learning for citizen-centric public services: A case study of a local government Facebook use," Gov. Inf. Q., vol. 34, no. 1, pp. 110-125, Jan. 2017.

[9] L. Zhu, F. R. Yu, Y. Wang, B. Ning, and T. Tang, "Big Data Analytics in Intelligent Transportation Systems: A Survey,” IEEE Trans. Intell. Transp. Syst., pp. 1-16, 2018.

[10] M. A. Alsheikh, D. Niyato, S. Lin, H. Tan, and Z. Han, "Mobile big data analytics using deep learning and apache spark," IEEE Netw., vol. 30, no. 3, pp. 22-29, May 2016.

[11] R. Myung, H. Yu, and D. Lee, "Optimizing Parallelism of Big Data Analytics at Distributed Computing System," vol. 7, no. 5, pp. 1716-1721, 2017.

[12] J. R. Kalyvas and M. R. Overly, Big Data: A Business and Legal Guide. London: CRC Press, 2014.

[13] F. Nasution, N. E. Nazira Bazin, - Daliyusmanto, and A. Zulfikar, "Big Data's Tools for Internet Data Analytics: Modelling of System Dynamics,” Int. J. Adv. Sci. Eng. Inf. Technol., vol. 7, no. 3, p. 745, 2017.

[14] N. Kitcharoen, S. Kamolsantisuk, R. Angsomboon, and T. Achalakul, "RapidMiner framework for manufacturing data analysis on the cloud," in Proceedings of the 2013 10th International Joint Conference on Computer Science and Software Engineering, JCSSE 2013, 2013, pp. 149-154.

[15] V. Ravindran, Sharan Kumar Garg, Mastering Social Media Mining with R. Birmingham: Packt Publishing Ltd., 2015. 